\title{
Low energy reserves are associated with fasting susceptibility in Neotropical nectar bats Glossophaga soricina
}

\author{
T. S. Amaral , E. C. Pinheiro $^{b}$, M. B. Freitas ${ }^{*}$ and L. M. S. Aguiar ${ }^{a}$ \\ aLaboratório de Biologia e Conservação de Morcegos, Departamento de Zoologia, Universidade de Brasília - UnB, \\ Campus Universitário Darcy Ribeiro, Asa Norte, CEP 70910-900, Brasília, DF, Brasil \\ 'Laboratório de Metabolismo, Departamento de Ciências Fisiológicas, Universidade de Brasília - UnB, \\ Campus Universitário Darcy Ribeiro, Asa Norte, CEP 70910-900, Brasília, DF, Brasil \\ 'Laboratório de Ecofisiologia de Quirópteros, Departamento de Biologia Animal, Universidade Federal de Viçosa - UFV, \\ Campus UFV, Av. P.H. Rolfs, CEP 36570-000, Viçosa, MG, Brasil \\ *e-mail:mfreitas@ufv.br
}

Received: September 23, 2016 - Accepted: October 9, 2017 - Distributed: May 31, 2019

\begin{abstract}
Neotropical nectar-feeding bats consume large amounts of sugar and use most of their energy-rich diet directly from the bloodstream, suggesting an adaptation towards lower body energy reserves. Here we tested the hypothesis that bats Glossophaga soricina spare the energy costs of storing energy reserves, even if this would represent a risky susceptibility during fasting. Blood glucose concentrations in $18 \mathrm{~h}$ fasted bats showed a $40 \%$ decrease. Breast muscle and adipose tissue lipids, as well as carcass fatty acids and liver glycogen, were also decreased following fasting. The inability to keep normoglycemia following a short-term fasting (i.e. $28 \mathrm{~h}$ ) confirm that nectar bats invest little on storing energy reserves and show a severe fasting susceptibility associated to this pattern. Our study also support the general hypothesis that evolutionary specializations towards nectar diets involve adaptations to allow a decreased body mass, which reduces the energy costs of flight while increases foraging time.
\end{abstract}

Keywords: Chiroptera, blood glucose, glycogen, lipid reserves, starvation.

\section{Baixas reservas energéticas corporais estão associadas à susceptibilidade ao jejum da espécie Glossophaga soricina}

\section{Resumo}

Morcegos nectarívoros que ocorrem na região Neotropical consomem grandes quantidades de carboidratos, e usam a energia obtida da dieta diretamente, a partir da glicose na circulação sanguínea. Esta adaptação sugere que morcegos nectarívoros tenham evoluído no sentido de apresentar adaptações fisiológicas que permitam o baixo armazenamento de reservas energéticas corporais. Nós testamos a hipótese de que morcegos Glossophaga soricina poupam o gasto energético envolvido com a formação de reservas energéticas teciduais, mesmo que isso represente uma arriscada suscetibilidade da espécie frente ao jejum. As concentrações de glicose apresentaram uma diminuição de $40 \%$ após $18 \mathrm{~h}$ de jejum. As concentrações de lipídios do músculo peitoral e do tecido adiposo, bem como as de ácidos graxos da carcaça e glicogênio hepático também diminuíram após $18 \mathrm{~h}$ de jejum. A incapacidade de manter a normoglicemia observada após o jejum de curto-prazo confirma que morcegos nectarívoros desta espécie não investem na formação de reservas energéticas, e apresentam, consequentemente, uma severa susceptibilidade ao jejum. Este estudo suporta a hipótese de que adaptações evolucionárias da espécie envolvem diminuição da massa corporal, reduzindo o custo energético do voo e aumentado o tempo de forrageamento.

Palavras-chave: Chiroptera, glicose sanguínea, glicogênio, lipídios, jejum.

\section{Introduction}

Vertebrates that consume different diets often differ in the way they store and mobilize body energy reserves, and therefore it is expected different species to have different responses to fasting. Although bats have the largest variety of diets among all mammalian orders, data on physiological responses to fasting in bats are restricted to a few frugivorous, insectivorous and hematophagous species (Ben-Hamo et al., 2012).

Nectarivorous bats stand out for their ecological role in pollinating plants (Fleming and Sosa, 1994; Kunz et al., 2011). Their extraordinary energy-rich diet is based mainly on sugar, since nectar consists basically of a solution 
of glucose, fructose and sucrose (Baker et al., 1998). While taking advantage of this high sugar food source, nectar bats also must face the challenge of dealing with post-feeding hyperglycemia (Helversen and Winter, 2003). Some physiological adaptations to this unusual diet have been reported for Glossophaga soricina (Pallas, 1766), including enhanced glucose absorption through higher intestinal sucrase activity (Hernandez and Martínez del Rio, 1992) and direct use of recently-ingested sugar for high muscle activity (Suarez et al., 2011; Kelm et al., 2011).

Considering these unique adaptations among mammals, we would expect that sparing the energy cost of converting sugar into fat for future use would be advantageous, specially to maintain a low body mass. However, this would implicate in lower energy reserves, raising the problem on how to deal with fasting. The aim of this study was to determine blood glucose, liver and muscle glycogen, muscle and adipose lipids and carcass fatty acids in Pallas's long-tongued bats (Glossophaga soricina) fed and fasted for 12,18 and $24 \mathrm{~h}$.

\section{Material and Methods}

\subsection{Animals}

Adult male nectar bats Glossophaga soricina (Pallas, 1766) $(\mathrm{n}=52)$ were captured in the region of Brasilia, DF, Brazil ( $15^{\circ} 47$ 'S, $\left.4753^{\prime} \mathrm{W}\right)$. All bats were immediately brought to the lab and kept in the Bioterium of the Biology Institute, University of Brasilia, for two days. Bats were kept in cages $(33 \times 46 \times 23 \mathrm{~cm})(5$ bats each cage $)$ installed in a 15 -square-meter room, with $12 \mathrm{~h}$ light:dark cycle. During this period, bats were fed bananas, papayas and vitamin supplement for hummingbirds (Alcon Pet ${ }^{\circledR}$, São Paulo, Brazil) with $25 \%$ sucrose concentration, while held in the hand. Water was provided ad libitum. After the 2-days acclimation period, bats were divided in four groups: 1) Control (FED, $\mathrm{n}=17)$; 2) $12 \mathrm{~h}$ fasted bats $(\mathrm{F} 12, \mathrm{n}=13) ; 3) 18 \mathrm{~h}$ fasted bats $(\mathrm{F} 18, \mathrm{n}=15)$; and 4$) 24 \mathrm{~h}$ fasted bats $(F 24, n=7)$. Fasting treatment started three hours after the last feeding. During the fasting period, all bats received water ad libitum. The experimental $\mathrm{N}$ was calculated based on a desired statistical power level of 0.8 and a $\mathrm{P}$ level of 0.05 ( $\mathrm{n}=14$ per group). Because we are using wild bats as experimental models, we tried to stay near this value, but we were limited by the amount of adult male bats we could capture in the same season. This work was developed under Federal license
SISBIO from the Institute for Biodiversity Conservation (MMA number 39296-1) and also under consent of the Ethics Committee on Animal Use at the University of Brasília (UnBDOC No. 116319/2011).

\subsection{Sample preparation}

Following the experimental period, all animals were euthanized. Blood, liver, breast muscle, adipose tissue and carcasses were collected for subsequent processing. To obtain the plasma, blood was collected directly into heparinized tubes and centrifuged (2000 rpm x $10 \mathrm{~min}$ ). Plasma glucose concentration was determined by the method of glucose oxidase (Glucox 500 kit, Doles, Goiânia, Brazil). Liver and muscle glycogen was measured according to Sjörgren et al. (1938). Total lipids of breast muscle and adipose tissue were determined gravimetrically, according to Folch et al. (1957). Carcass fatty acids were determined after digestion in $100 \mathrm{~mL}$ of $\mathrm{KOH}(6 \mathrm{~N})$, filtration and addition to an equal volume of absolute alcohol to obtain a $\mathrm{KOH}$-ethanol solution $(50 \% \mathrm{v} / \mathrm{v})$. After manual agitation for extraction with chloroform ( $25 \mathrm{~mL}$ for $1 \mathrm{~min}, 3 \mathrm{x})$, the supernatant was collected and the carcass fatty acids concentration was determined gravimetrically (Folch et al., 1957).

\subsection{Statistical analyses}

All data were analyzed (Statistica, StatSoft ${ }^{\circledR}$ ) using one-way ANOVA followed by the Tukey's test or Kruskal-Wallis test (for nonparametric data), depending on the assumptions of normality and homoscedasticity. Statistical significance was set at $p<0.05$. Data can be obtained in detail directly with the corresponding author.

\section{Results}

Results are shown in Table 1. Six out of seven bats from the F24 group died before the procedures, though we decided to exclude this group from our experimental design. All bats from the other groups (FED, F12 and F18) were alert and able to fly until the time the end of the experiment. Blood glucose concentrations were decreased in $\mathrm{F} 18$ bats compared with the FED group $\left(F_{2,40}=6.76, P<0.001\right)$. Liver glycogen concentrations were also decreased in F18 compared to $\operatorname{FED}\left(H_{2,43}=18.27, P=0.05\right)$. Breast muscle glycogen was decreased in both $\mathrm{F} 12$ and $\mathrm{F} 18$ fasted groups $\left(H_{2.44}=5.78, P<0.001\right)$. Breast muscle and adipose tissue lipids, as well as carcass fatty acids, were decreased in F18 compared to the FED bats $\left(H_{2,40}=10.20, P=0.006\right.$; $\left.H_{2,31}=11.48, P=0.00 ; H_{2,44}=17.47, P<0.001\right)$.

Table 1. Metabolic parameters in fed nectar-feeding bats and following 12 (F12) and 18 (F18) hours of fasting.

\begin{tabular}{lccc}
\hline & FED & F12 & F18 \\
\hline Blood glucose $\left(\mathrm{mmol}^{-1}\right)$ & $5.5 \pm 0.54^{\mathrm{a}}$ & $4.15 \pm 0.38^{\mathrm{a}}$ & $3.3 \pm 0.21^{\mathrm{b}}$ \\
Liver glycogen $\left(\mu \mathrm{mol}^{-1}\right.$ glicosil- units/g) & $485.92 \pm 50.47^{\mathrm{a}}$ & $358.26 \pm 71.08^{\mathrm{a}}$ & $221.56 \pm 14.36^{\mathrm{b}}$ \\
Breast muscle glycogen $\left(\mu \mathrm{mol}^{-1}\right.$ glicosil- units $\left./ \mathrm{g}\right)$ & $148.55 \pm 13.37^{\mathrm{a}}$ & $124.71 \pm 9.14^{\mathrm{b}}$ & $114.98 \pm 7.41^{\mathrm{b}}$ \\
Breast muscle lipids $\left(\mathrm{g} .100 \mathrm{~g}^{-1}\right)$ & $17.91 \pm 4.21^{\mathrm{a}}$ & $36.21 \pm 7.96^{\mathrm{a}}$ & $8.58 \pm 1.05^{\mathrm{b}}$ \\
Adipose tissue lipids $\left(\mathrm{g} .100 \mathrm{~g}^{-1}\right)$ & $29.18 \pm 4.89^{\mathrm{a}}$ & $37.88 \pm 11.79^{\mathrm{a}}$ & $12.80 \pm 0.87^{\mathrm{b}}$ \\
Carcass fatty acids $\left(\mathrm{g} .100 \mathrm{~g}^{-1}\right)$ & $2.22 \pm 0.15^{\mathrm{a}}$ & $2.63 \pm 0.69^{\mathrm{a}}$ & $1.29 \pm 0.08^{\mathrm{b}}$ \\
\hline
\end{tabular}

Different letters indicate statistical differences. 


\section{Discussion}

Overall, we observed decreases in all tested energy reserves after 18 hours of fasting in Glossophaga soricina, although blood glucose levels failed to remain constant during short-term fasting. In mammals, glucose is the main energy molecule, and its declining circulating levels are considered a homeostatic imbalance signal, since it demonstrates that the body can no longer maintain normoglycemia (Cryer, 1991). Most bats, including species fed a variety of foods, use their body energy reserves, especially liver glycogen and lipid stores in the adipose tissue, to produce glucose to be released in the bloodstream via glucogenolysis and gluconeogenesis (Widmaier and Kunz, 1993; Freitas et al., 2003; Pinheiro et al., 2006; Melo et al., 2012; Amaral et al., 2012a, 2012b; Barros et al., 2013). Most mammals depend on this liver pathway to obtain glucose when food is not available (McCue, 2010). Unlike this pattern, we demonstrated that nectar-feeding bats had their glycogen and lipid stores mobilized after 18 hours, but failed to convert these energy substrates into glucose, proving their inability to maintain blood glucose levels following a short-term fasting.

Blood glucose concentration observed in G. soricina fasted for $18 \mathrm{~h}$ was similar to the value found in frugivorous bats fasted for 48 hours (Pinheiro et al., 2006). Unlike nectar bats, fruit bats could keep blood glucose levels stable for up to 6 days of fasting. The amount of nectar bats that could not survive the $24 \mathrm{~h}$ challenge also indicates that $G$. soricina is clearly more sensitive to fasting periods.

In the same way as blood glucose, liver glycogen also decreased after $12 \mathrm{~h}$ of fasting. Liver glycogen reserves provide a rapid source of glucose to the bloodstream (Casey, 2003; Kraus-Friedmann, 1984). The same pattern of liver glycogen mobilization was observed in fruit-eating bats (Pinheiro et al., 2006) and vampire bats (Freitas et al., 2003; 2005). Glossophaga soricina seems to use this carbohydrate reserve to supply energy during foraging periods. This nectar-feeding species. Glossophagine bats have undergone evolutionary convergence with hummingbirds (Welch et al., 2008). As hovering flight is energetically very costly, nectar-bats show some of the highest known mass-specific metabolic rates (Suarez et al., 2011).

Although lipid reserves are important for bats dealing with fasting (Freitas et al., 2003; Pinheiro et al., 2006), and also for providing and efficient energy source for bats during reproduction (Barros et al., 2013) and to deal with increased foraging time due to habitat degradation (Melo et al., 2012), among other activities, nectar feeding bats seem to have evolved to a metabolic pattern that made them able to live with less energy reserves. It is known that up to $95 \%$ of the daily energy use by G. soricina is provided by exogenous glucose intake from their diets (Voigt and Speakman, 2007; Welch et al., 2008), using directly the bloodstream as the main source of glucose for their activities, such as flight (Voigt and Speakman, 2007; Welch et al., 2008). This mechanism would allow them to meet their high energy demands and also regulate their blood glucose levels at the same time (Kelm et al., 2011).
In the Cerrado area, G. soricina faces a large variety of food items. Its diet consists of pollen, nectar, fruit and insects (Zortéa, 2003). It is also reported some variation on these items proportions according to different seasons (Voigt and Speakman, 2007).

Regarding the lipid reserves, the observed decreased after $18 \mathrm{~h}$ of fasting may result from gluconeogenesis, which may provide free fatty acids and glycerol to the meet these high energy demands. Taken together, the energy reserves we found in G. soricina is very limited compared to fruit (Pinheiro et al., 2006) or insect-eating bats (Freitas et al., 2006)

A similar condition is observed in vampire bats, which also struggle to deal with fasting for having evolved to prioritize a lower and more flight efficient body mass over storing energy reserves (Freitas et al., 2003). Although vampires' susceptibility seem to be driven by opposite mechanisms (in their case, a low carbohydrate, protein-rich diet), vampires also have to deal with a metabolism designed to spare the costs of energy turnover. In both cases, compensatory behavioral mechanisms seem to play important roles for energy adjustments to very unique diets.

We conclude that the nectarivorous bat Glossophaga soricina are critically susceptible to fasting for presenting poor energy stores, which are mobilized after 18 hours of fasting. Lacking body energy stores, nectar feeding bats became more susceptible to fasting. Not being able to maintain normoglycemia after this period, fasting may lead them to die after $24 \mathrm{~h}$ of food absence. This condition may be associated with their extremely high-carbohydrate diet and the high foraging cost of this species.

\section{Acknowledgements}

We thank the National Council for Scientific and Technological Development (CNPq) and the Academic English Solutions (AES) for revising the English version.

\section{References}

AMARAL, T.S., CARVALHO, T.F., SILVA, M.C., BARROS, M.S., PICANÇO, M., NEVES, C.A. and FREITAS, M.B., 2012a. Short-term effects of a spinosyn's family insecticide on energy metabolism and liver morphology in frugivorous bats. Brazilian Journal of Biology $=$ Revista Brasileira de Biologia, vol. 72, pp. 299-304. http://dx.doi.org/10.1590/S1519-69842012000200010. PMid:22735137.

AMARAL, T.S., CARVALHO, T.F., SILVA, M.C., GOULART, L.S., BARROS, M.S., PICANÇO, M.C., NEVES, C.A. and FREITAS, M.B., 2012b. Metabolic and histopathological alterations in the fruit-eating bat Artibeus lituratus induced by the organophosphorous pesticide fenthion. Acta Chiropterologica, vol. 14, no. 1, pp. 225-232. http://dx.doi.org/10.3161/150811012X654420.

BAKER, H.G., BAKER, I. and HODGES, A.S., 1998. Sugar composition of nectars and fruits consumed by birds and bats in the tropics and subtropics. Biotropica, vol. 30, no. 4, pp. 559-586. http://dx.doi.org/10.1111/j.1744-7429.1998.tb00097.x. 
BARROS, M.S., MORAIS, D.B., ARAUJO, M.R., CARVALHO, T.F., MATTA, S.L.P., PINHEIRO, E.C. and FREITAS, M.B., 2013. Seasonal variation of energy reserves and reproduction in neotropical free-tailed bats Molossus molossus (Chiroptera: Molossidae). Brazilian Journal of Biology = Revista Brasileira de Biologia, vol. 73, no. 3, pp. 629-635. http://dx.doi.org/10.1590/ S1519-69842013000300022. PMid:24212705.

BEN-HAMO, M., MUÑOZ-GARCIA, A. and PINSHOW, B. 2012. Physiological responses to fasting in bats. In: M. D. McCue, ed. Comparative physiology of fasting, starvation, and food limitation. Berlin: Springer Berlin Heidelberg, Inc. pp. 257275. http://dx.doi.org/10.1007/978-3-642-29056-5_16.

CASEY, A., 2003. Hormonal control of metabolism: regulation of plasma glucose. Surgery, vol. 21, no. 5, pp. 128a-128d.

CRYER, P.E., 1991. Regulation of glucose metabolism in man. Journal of Internal Medicine, vol. 735, pp. 31-39. PMid:1675054.

FLEMING, T.H. and SOSA, V.J., 1994. Effects of nectarivorous and frugivorous mammals on reproductive success of plants. Journal of Mammalogy, vol. 75, no. 4, pp. 847-851. http://dx.doi. org/10.2307/1382466.

FOLCH, J., LESS, M. and STANLEY, G.H.S., 1957. A simple method for the isolation and purification of total lipids from animal tissues. The Journal of Biological Chemistry, vol. 226, no. 1, pp. 497-509. PMid:13428781.

FREITAS, M.B., PASSOS, C.B.C., VASCONCELOS, R.B. and PINHEIRO, E.C., 2005. Effects of short-term fasting on energy reserves of vampire bats (Desmodus rotundus). Comparative Biochemistry and Physiology. Part B, Biochemistry \& Molecular Biology, vol. 140, no. 1, pp. 59-62. http://dx.doi.org/10.1016/j. cbpc.2004.09.023. PMid:15621510.

FREITAS, M.B., WELKER, A.F. and PINHEIRO, E.C., 2006. Seasonal variation and food deprivation in common vampire bats (Chiroptera: Phyllostomidae). Brazilian Journal of Biology $=$ Revista Brasileira de Biologia, vol. 66, no. 4, pp. 1051-1055. http:// dx.doi.org/10.1590/S1519-69842006000600012. PMid:17299941.

FREITAS, M.B., WELKER, A.F., MILLAN, S.F. and PINHEIRO, E.C., 2003. Metabolic responses induced by fasting in the common vampire bat Desmodus rotundus. Comparative Biochemistry and Physiology. Part B, Biochemistry \& Molecular Biology, vol. 173, no. 8, pp. 703-707. http://dx.doi.org/10.1007/s00360-003-0383-3. PMid:13680131.

HELVERSEN, O.V. and WINTER, Y. 2003. Bats and flowers. In: T. H. Kunz and M. B. Fenton, eds. Bat ecology. Chicago: University of Chicago Press. pp. 346-397.

HERNANDEZ, A. and MARTINEZ DEL RIO, C., 1992. Intestinal disaccharidases in five species of phyllostomid bats. Comparative Biochemistry and Physiology. B, Comparative Biochemistry, vol. 103, no. 1, pp. 105-111. http://dx.doi.org/10.1016/03050491(92)90420-V. PMid:1451428.

KELM, D.H., SIMON, R., KUHLOW, D., VOIGT, C.C. and RISTOW, M., 2011. High activity enables life on a high-sugar diet: blood glucose regulation in nectar-feeding bats. Proceedings. Biological sciences / The Royal Society, vol. 278, no. 1724, pp. 34903496. http://dx.doi.org/10.1098/rspb.2011.0465. PMid:21490011.
KRAUS-FRIEDMANN, N., 1984. Hormonal regulation of hepatic gluconeogenesis. Physiological Reviews, vol. 64, no. 1, pp. 170-259. http://dx.doi.org/10.1152/physrev.1984.64.1.170. PMid:6141578.

KUNZ, T.H., TORREZ, E.B., BAUER, D., LOBOVA, T. and FLEMING, T.H., 2011. Ecosystem services provided by bats. Annals of the New York Academy of Sciences, vol. 1223, no. 1, pp. 1-38. http://dx.doi.org/10.1111/j.1749-6632.2011.06004.x. PMid:21449963.

MCCUE, M.D., 2010. Starvation physiology: reviewing the different strategies animals use to survive a common challenge. Comparative Biochemistry and Physiology. Part A, Molecular \& Integrative Physiology, vol. 156, no. 1, pp. 1-18. http://dx.doi. org/10.1016/j.cbpa.2010.01.002. PMid:20060056.

MELO, B.E.S., BARROS, M.S., CARVALHO, T.F., AMARAL, T.S. and FREITAS, M.B., 2012. Energy reserves of Artibeus lituratus (Chiroptera: Phyllostomidae) in two areas with different degrees of conservation in Minas Gerais. Brazilian Journal of Biology = Revista Brasileira de Biologia, vol. 72, pp. 181-187. http:// dx.doi.org/10.1590/S1519-69842012000100022. PMid:22437400.

PINHEIRO, E.C., TADDEI, V.A., MIGLIORINI, R.H. and KETTELHUT, I.C., 2006. Effect of fasting on carbohydrate metabolism in frugivorous bats (Artibeus lituratus and Artibeus jamaicensis). Comparative Biochemistry and Physiology. Part B, Biochemistry \& Molecular Biology, vol. 143, no. 3, pp. 279-284. http://dx.doi.org/10.1016/j.cbpb.2005.11.013. PMid:16455278.

SJÖRGREN, B., NOERDENSKJOLD, T., HOLMGEEN, H. and MOLLERSTRÖM, J., 1938. Beitrag zur kenntnis der leberrhythmik (glykogen, phosphor und calcium in der kaninchenleber). European Journal of Phycology, vol. 240, pp. 427-432.

SUAREZ, R.K., HERRERA M, L.G. and WELCH, K.C. Jr, 2011. The sugar oxidation cascade: aerial refueling in hummingbirds and nectar bats. The Journal of Experimental Biology, vol. 214, no. Pt 2, pp. 172-178. http://dx.doi.org/10.1242/jeb.047936. PMid:21177938.

VOIGT, C.C. and SPEAKMAN, J.R., 2007. Nectar-feeding bats fuel their high metabolism directly with exogenous carbohydrates. Functional Ecology, vol. 21, no. 5, pp. 913-921. http://dx.doi. org/10.1111/j.1365-2435.2007.01321.x.

WELCH, K.C. Jr., HERRERA M, L.G. and SUAREZ, R.K., 2008. Dietary sugar as a direct fuel for flight in the nectarivorous bat Glossophaga soricina. The Journal of Experimental Biology, vol. 211, no. Pt 3, pp. 310-316. http://dx.doi.org/10.1242/jeb.012252. PMid:18203985.

WIDMAIER, E.P. and KUNZ, T.H., 1993. Basal, diurnal, and stress-induced levels of glucose and glucocorticoids in captive bats. The Journal of Experimental Biology, vol. 265, no. 5, pp. 533-540. PMid:8468542.

ZORTÉA, M., 2003. Reproductive patterns and feeding habits of three nectarivorous bats (phyllostomidae: glossophaginae) from the brazilian cerrado. Brazilian Journal of Biology $=$ Revista Brasileira de Biologia, vol. 63, no. 1, pp. 159-168. http://dx.doi. org/10.1590/S1519-69842003000100020. PMid:12914427. 